\title{
Effects of ambient UVB radiation in a meiobenthic community of a tidal mudflat
}

\author{
Christian Nozais*, Gaston Desrosiers, Michel Gosselin, Claude Belzile, Serge Demers
}

Groupe de recherche en environnement côtier, Institut des sciences de la mer, Université du Québec à Rimouski, 310 allée des Ursulines, Rimouski, Québec G5L 3A1, Canada

\begin{abstract}
Most studies involving UVB radiation effects in the marine environment have focused mainly on planktonic communities. Despite the importance of shallow-water sediments as nursery and feeding areas for various taxa, investigations of the impact of UVB radiation on meiobenthic communities are still scarce. A microcosm experiment was conducted over a $42 \mathrm{~d}$ period with a microbenthic community in a tidal mudflat of the Lower St. Lawrence Estuary, Canada, in order to assess the influence of ambient UVB radiation on the abundance of ontogenic stages of harpacticoid copepods, on nematodes, and on chlorophyll a and pheopigment concentrations. The microbenthic community within non-perturbed sediment cores was exposed to 2 different light regimes: natural irradiance (natural UVB) and reduced UVB. Sampling of the sediment cores was carried out on a weekly basis. There was a significant decrease in chlorophyll a concentrations in reduced UVB microcosms on Days 7 and 14, and no significant difference thereafter. A negative impact of UVB was observed upon meiobenthic copepod nauplii and copepodites. Adult harpacticoid copepods were significantly less abundant in the reduced UVB treatment on Day 7 . There was no significant difference in the abundance of adult harpacticoid copepods between treatments at subsequent sampling dates and no effect on nematode abundance for the whole experiment. Our results suggest that natural UVB radiation may have a deleterious effect on the naupliar stages of harpacticoid copepods, a key group of the meiobenthic compartment. Thus, a change in UVB radiation may greatly influence the dynamics of intertidal populations of copepods by affecting their recruitment. Since meiofauna plays a key role in energy fluxes throughout the benthic food web, structural changes of harpacticoid populations induced by UVB radiation may significantly reduce nutrient transport at the water-sediment interface and the availability of food in the upper trophic levels.
\end{abstract}

KEY WORDS: Ultraviolet radiation - Intertidal mudflat · Harpacticoid copepods · Nematodes Microphytobenthos - Microcosms

\section{INTRODUCTION}

The discovery of an increased UVB radiation flux (UVB; 280 to $320 \mathrm{~nm}$ ) reaching the Earth's surface, due to stratospheric ozone depletion at both temperate (Kerr \& McElroy 1993) and polar latitudes (Farman et al. 1985, Lubin \& Jensen 1995, Müller et al. 1997, Rex et al. 1997), has led to increased attention on its influence on aquatic ecosystems (Karentz 1994, Williamson 1995j. It is clear that ambient UVB constitutes a source of stress for individual components of pelagic commu-

\footnotetext{
- Present address: University of Durban-Westville, Marine Science Unit, Private Bag X54001, Durban 4000, South Africa.E-mail: nozais@pixie.ndw.ac.za
}

nities, both in marine and freshwater environments (Smith et al. 1980, Cullen \& Lesser 1991, Häder 1993, Herndl et al. 1993, Buma et al. 1996), and may influence the entire community structure (Mostajir et al. 1999).

By comparison, investigations assessing the effects of UVB on benthic communities are scarce, despite their great ecological importance. Shallow-water sediments support a rich benthic community, serve as nursing and feeding grounds for various taxa (Reise 1985) and are suspected to be substantial local sources of carbon (Bothwell et al. 1993, Pinckney \& Zingmark 1993, Garcia-Pichel \& Castenholz 1994, Peletier et al. 1996). Considerable attention has been directed towards the effects of UVB on adult stages of epibenthic 
macroinvertebrates (Karentz et al. 1991, Shick et al. 1992, Gleason \& Wellington 1993, Bothwell et al. 1994, Lesser \& Lewis 1996, Hill et al. 1997, Kiffney et al. 1997. McClintock \& Karentz 1997). On the other hand, substantially less is known about the susceptibility of alternate stages (i.e. benthic embryos or planktonic larvae) of benthic organisms having a complex life cycle to UVB (Pennington \& Emlet 1986, Bierman et al. 1992, Gleason \& Wellington 1995, Adams \& Shick 1996, Morgan \& Christy 1996, Rawlings 1996). Alternate stages (planktonic larvae) of many marine organisms are known to experience extremely different light regimes (Thorson 1964). Compared to their benthic adult counterparts, the barely motile planktonic larvae may be exposed to higher doses of UV radiation during their development.

Recent measurements have shown that shallow waters enable UV radiation to reach the sediment surface. In addition, UVB levels may be high in the euphotic strata of the sediment (Garcia-Pichel 1995). Garcia-Pichel \& Bebout (1996) reported that $1 \%$ of the incident UVB at $310 \mathrm{~nm}$ reached $0.23 \mathrm{~mm}$ in the silty mud intertidal sediments of the Wadden Sea. The benthic communities of the intertidal zone experience fluctuating tidal cycles, and thus huge changes in environmental variables, including solar irradiation. When exposed to air at low tide, benthic organisms at the sediment surface are subjected to the highest UV irradiance that can be experienced by aquatic organisms. Thus, the ecological implications of enhanced UVB for benthic communities should be assessed (Vincent \& Quesada 1994). Both autotrophic and heterotrophic components of microbenthic communities may develop a complex response to UVB which involves both direct and indirect effects (Bothwell et al. 1994, Sundbäck et al. 1996a). Recently Odmark et al. (1998), in a 3 wk experiment, found that ambient UVB can exert a stress on the function of sand-associated microbenthic communities. They concluded, however, that meiofaunal biomass and composition were not significantly affected by UVB radiation. To our knowledge, the only existing study assessing the ecological effects of ambient UVB on both microphytobenthos and mud-associated meiofauna of shallow waters was carried out on a microtidal area by Sundbäck et al. (1996a). They concluded that ambient UVB did not exert any strong selective pressure on the particular type of community studied.

The aim of this study was to assess the response of 2 components of the benthic meiofauna (harpacticoid copepods and nematodes) and sediment-associated microalgae (microphytobenthos) to ambient UVB exposure in an intertidal mudflat. We focused on ontogenic stages of copepods (larval, juvenile and adult stages) and on nematodes because (1) they may account for more than $90 \%$ of the total abundance of meiofauna in mud environments (Giere 1993), and (2) due to their confinement in the oxidized layers of the sediment (usually the top $1 \mathrm{~cm}$ ) (Coull \& Bell 1979), they are more susceptible to suffer from direct and/or indirect effects of UVB (i.e. generation of hydrogen peroxide, reduction of food supply for meiofauna). Potential UVB effects on ontogenic stages of harpacticoid copepods and on nematodes were assayed by measuring their abundance under natural ambient irradiance and reduced UVB treatments. The response of microphytobenthos to UVB levels was based on changes in chlorophyll a (chl a) concentration.

\section{MATERIALS AND METHODS}

The study was conducted from 8 July to 19 August 1997 at the Pointe-au-Père nearshore station of the Université du Québec on the south shore of the Lower St. Lawrence Estuary, Québec, Canada. Sediment cores were sampled with transparent plexiglas tubes (inner diameter $68 \mathrm{~mm}$, length $80 \mathrm{~mm}$ ) from the top $7 \mathrm{~cm}$ of the upper tidal zone of a sheltered, north-east oriented cove, located in the Parc national du Bic $\left(68^{\circ} 48^{\prime} \mathrm{W} ; 48^{\circ} 20^{\prime} \mathrm{N}\right), 30 \mathrm{~km}$ west of Pointe-au-Père. The sampling site consists of a postglacial silt-clay deposit (Dionne 1977) covered by $3 \mathrm{~cm}$ of muddy sediment and $70 \mathrm{~cm}$ of water at high tide (Miron 1988). The sediment, with an organic matter content of about $3 \%$ (Miron \& Desrosiers 1990), is covered by a brown 1 to $2 \mathrm{~mm}$ thick cohesive mat. In the summertime, the temperature of the sediment varies between 3 and $20^{\circ} \mathrm{C}$ during the day and between 3 and $14^{\circ} \mathrm{C}$ at night (Desrosiers et al. 1991). Water temperature which is around $13^{\circ} \mathrm{C}$ at high tide in summer may reach $35^{\circ} \mathrm{C}$ in tide pools (Desrosiers unpubl. data).

The experiment was carried out in an outdoor flowthrough system formed by six 44 l plastic microcosms $(650 \times 380 \mathrm{~mm}$, height $180 \mathrm{~mm})$ supplied with the same filtered seawater (serial filtering on cotton cartridge filters of 50,5 , and $1 \mu \mathrm{m}$ ) contained in a 800 l plastic tank. The seawater was pumped from a $10 \mathrm{~m}$ depth in front of the nearshore station. The water circulation was insured by a Little Giant ${ }^{\star}$ pump which was submerged in the tank. The flow rate was 86 to $91 \mathrm{l} \mathrm{h}^{-1}$ within each microcosm, corresponding to a turnover time of $0.5 \mathrm{~h}$. Filtered seawater in the tank was changed every morning. A semidiurnal tide ( $\mathrm{M}_{2}$ : tidal wave component) was provided in microcosms according to the natural tidal cycle at the sampling site (i.e. a progressive variation of the water level above the sediment surface). In our experiment, the water depth above the sediment was $10 \mathrm{~cm}$ at high tide and about $1 \mathrm{~cm}$ at low tide. The 2 treatments were: exposure to ambient UVB (natural 
UVB) and reduced UVB. The natural UVB microcosms were covered with a $0.13 \mathrm{~mm}$ cellulose acetate sheet (transmission properties in Fig. 1) to protect the cores from rain, dust and seabird feces. In the 'reduced UVB' microcosms, UVB was reduced using a $0.13 \mathrm{~mm}$ Mylar D sheet ( $50 \%$ transmission at 323 nm, Fig. 1). Cellulose acetate filters cut $9.1 \%$ of incident photosynthetically available radiation (PAR; 400 to $700 \mathrm{~nm}$ ), $12.2 \%$ of incident UVA ( 320 to $400 \mathrm{~nm}$ ) and $16.7 \%$ of incident UVB (280 to $320 \mathrm{~nm}$ ) compared to $13.4,28.4$ and $91.2 \%$, respecively, with Mylar D filters. Less than $0.1 \%$ of the incident irradiance between 280 and $314 \mathrm{~nm}$ was transmitted through Mylar D filters, while $82.3 \%$ passed through cellulose acetate filters. Both cellulose acetate and Mylar D sheets were replaced weekly to avoid modifications in transmission properties due to photodegradation. This is a standard protocol that enables us to compare our results with other studies (Sundbäck et al. 1996a, Odmark et al. 1998).

At the beginning of the experiment, 5 randomly chosen cores were placed in each of the 6 microcosms, and 3 cores were taken to determine the initial values. Sediment samples were then taken weekly (6 times, including initial sampling). At each sampling date, 1 core from each of the 6 microcosms was removed (i.e. 3 from each treatment). Pigment concentration and meiofaunal abundance (harpacticoid copepods and nematodes) were determined on sediment subsamples taken with a sharpened circular punch $9 \mathrm{~mm}$ inner diameter).

For the analysis of pigments, 2 sediment subsamples were taken from each core. Immediately after this process, subsamples were stored frozen at $-80^{\circ} \mathrm{C}$ for later analysis. All subsequent manipulations were done under dim light and at $4^{\circ} \mathrm{C}$. While the sediment was still partially frozen, the lower part of it, i.e. the postglacial silt-clay deposit, was discarded. The upper $10 \mathrm{~mm}$ of the sediment sample was then processed for the determination of chl $a$ and pheopigments according to the method of Riaux-Gobin \& Klein (1993), except that the sediment was freeze-dried prior to extraction in $90 \%$ acetone. Pigments were determined on a R010 Turner Designs fluorometer, using equations from Strickland \& Parsons (1972).

For the analysis of meiofauna, 3 sediment subsamples were taken from each core and preserved in $4 \%$ borax-buffered formaldehyde. Each sample was subsequently sieved on 500 and $63 \mu \mathrm{m}$ meshes. Harpacticoid copepods and nematodes were sorted from the $>63 \mu \mathrm{m}$ fraction, after staining in Rose Bengal, and counted. Ontogenic stages of harpacticoid copepods were identified as nauplii, copepodites and adults.

Incident PAR, UVA and UVB were recorded using an IL-1700 radiometer (International Light) every $10 \mathrm{~min}$ during the entire sampling period. The IL-1700 radio-

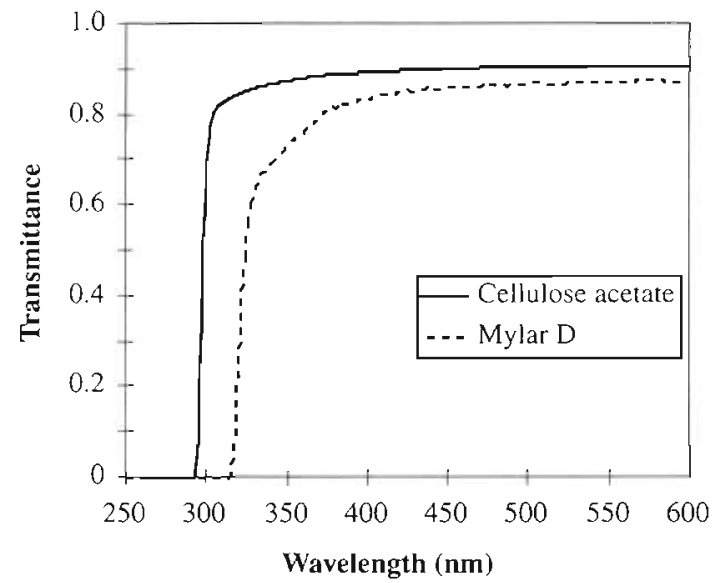

Fig. 1. Transmission spectra of cellulose acetate and Mylar D sheets placed over the microcosms

meter with SUD033/PAR/QNDS1/W (PAR), SUD033/ UV-A/W (UVA) and SUD240/SPS300/T/W (UVB) sensors provided cosine-corrected downwelling irradiance.

Treatment effects were tested with a nested ANOVA for each sampling date (Underwood 1981). The experimental treatments were 2 different light regimes (i.e. exposure to ambient UVB and reduced exposure to UVB) (Factor A). Three replicate cores (Factor B) were used for each treatment to estimate spatial variability in the effects of the treatments, and these are nested in the factor treatment. Tests for homogeneity of variances were performed with a test of Cochran, and when required, data were logarithm transformed $[\log (x+1)$ or $\log (x)]$. Differences at the $5 \%$ level were accepted as significant.

\section{RESULTS}

Incident solar radiation varied during the experimental period as a result of cloud cover and seasonal trends. During the experiment, $40 \%$ of the days were sunny, $14 \%$ were overcast, and $46 \%$ showed variable cloud cover. Typical incident irradiances at noon during sunny days were 1.11 to $1.57 \mathrm{~W} \mathrm{~m}^{-2}, 30$ to $34 \mathrm{~W} \mathrm{~m}^{-2}$ and 1690 to $1906 \mu \mathrm{E} \mathrm{m} \mathrm{m}^{-2} \mathrm{~s}^{-1}$ for UVB, UVA and PAR, respectively. During the experiment, UVB intensities under Mylar D filters did not exceed $3.49 \mathrm{~kJ} \mathrm{~m}^{-2} \mathrm{~d}^{-1}$ (Fig. 2). The weekly irradiances are presented in Fig. 3. Weeks 1 and 3 showed the highest irradiances, Weeks 2, 4 and 5 had intermediate values and Week 6 showed the lowest irradiances. The weekly integrated UVB in Week 6 was $41 \%$ lower than in the first week. During the experimental period, water temperature inside the cores varied between 13 (high tide) and $31^{\circ} \mathrm{C}$. (at low tide on sunny days). 

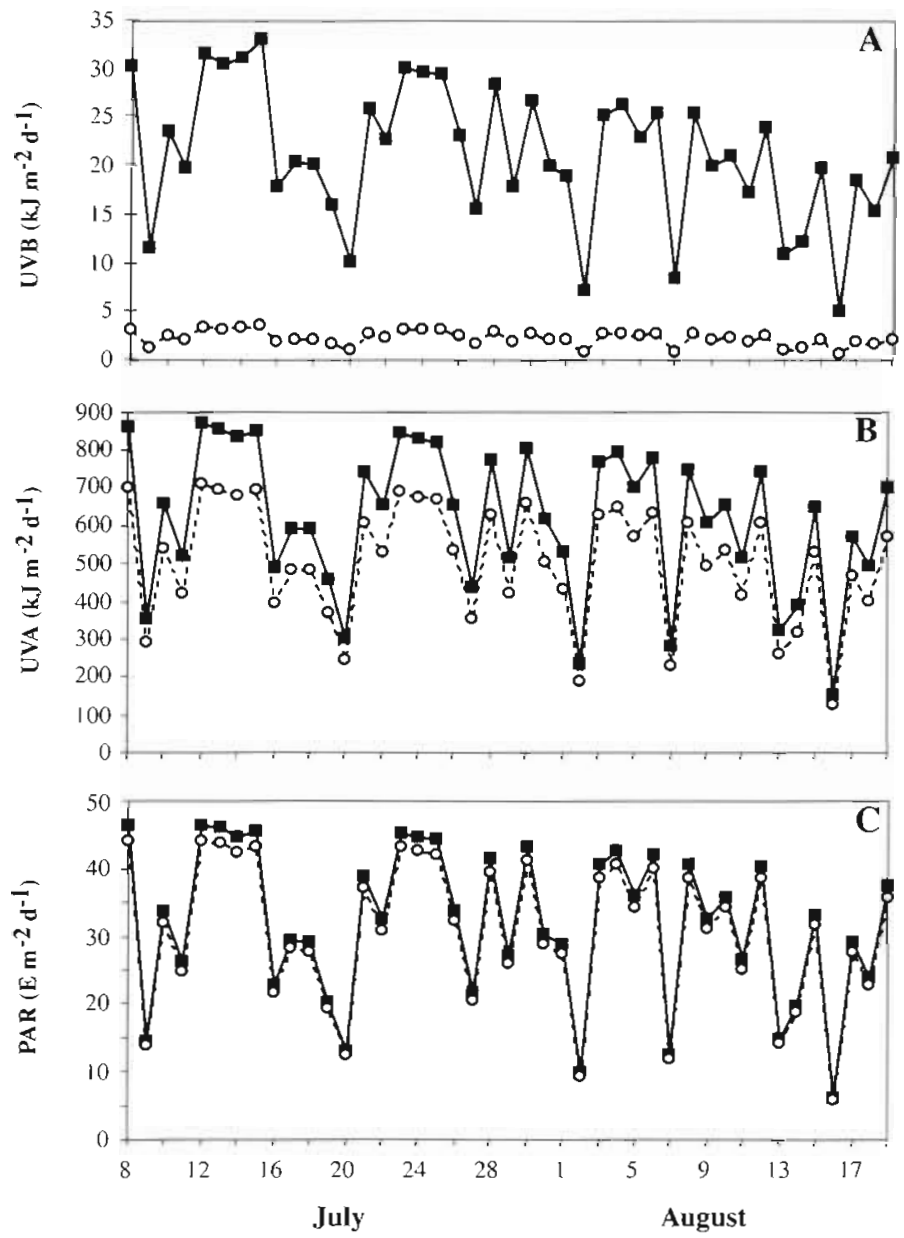

Fig. 2. Temporal variations of (A) UVB, (B) UVA and (C) PAR under cellulose acetate ( $)$ and Mylar D (O) filters during the experimental period

At the beginning of the experiment, the amount of chl $a$ in the sediment was $197 \pm 9 \mathrm{mg} \mathrm{m}^{-2}$ (Fig. 4A). Significant treatment effects on the amount of chl a were found on Days 7 and 14 (Table 1). Chl a concentrations were 1.5 and 1.35 times higher in the natural UVB microcosms than in the reduced UVB microcosms on Days 7 and 14, respectively. On Days 21, 28 and 42, chl a concentrations appeared higher in the reduced UVB microcosms, but these differences were not significant. Pheopigments varied between 88 and $166 \mathrm{mg}$ $\mathrm{m}^{-2}$ and were not significantly affected by the UVB treatment. No significant difference was found in the ratio of pheopigments to $\mathrm{chl}$ a.

The abundance of nematodes was initially $1355 \times$ $10^{3}$ ind. $\mathrm{m}^{-2}$ (Fig. $4 \mathrm{~B}$ ). In both treatments, there was a decreasing trend in nematode abundance. However, there was no significant effect of reduced UVB on nematode abundance during the entire sampling period (Table 1).
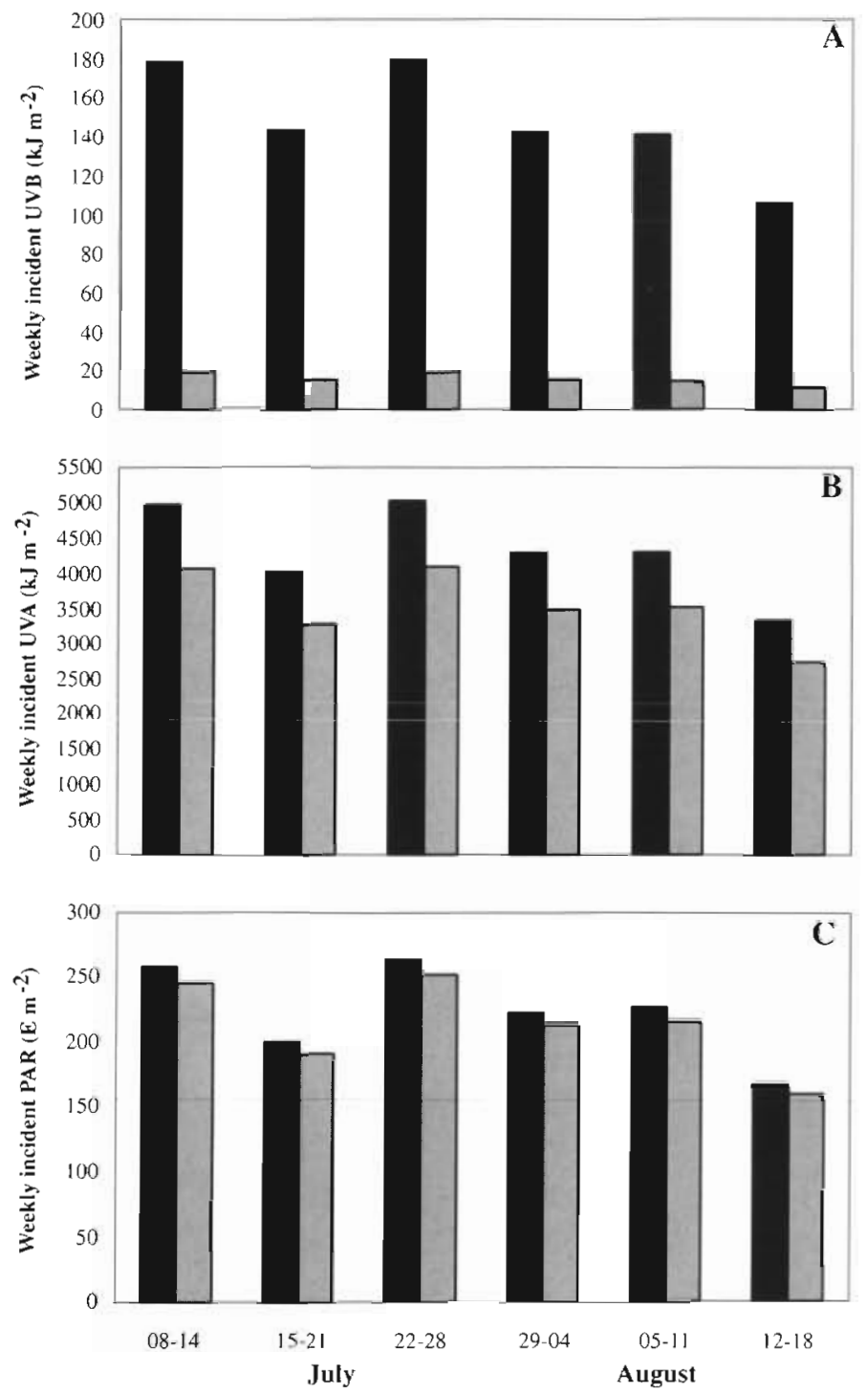

Fig. 3. Weekly irradiance of (A) UVB, (B) UVA and (C) PAR under cellulose acetate (natural UVB, black bars) and Mylar $D$ (reduced UVB, grey bars) filters during the experimental period

The copepod community was dominated by Microarthridion littorale, Stenhelia (D.) palustris, and Pseudobrodya curticorne, which together comprised $>90 \%$ of the total abundance of harpacticoid copepods (G. Tita \& M. Clément pers. comm.). The initial abundance of harpacticoid nauplii was $17466 \pm 4621$ ind. $\mathrm{m}^{-2}$ (Fig. 5A). The reduction of natural UVB had a significant effect on the nauplii abundance on Days 7, 14, 21 and 28 (Table 1). The same tendency, but not significant, was observed on Day 42. In the reduced UVB microcosms, the mean abundances of harpacticoid nauplii on Days 7,14,21, 28 and 42 were at least $50 \%$ higher than in the natural UVB microcosms. 
Table 1. Fvalues from a nested analysis of variance for chl a concentration and nematode, copepod nauplii, copepodite and adult harpacticoid copepod abundances in sediment. $\mathrm{p}$ values are presented in parentheses. The experimental treatments are 'natural UVB' versus 'no UVB' (Factor A). Three replicate cores (Factor B) were used for each treatment, and these are nested in the treatment factor

\begin{tabular}{|c|c|c|c|c|c|c|}
\hline Variable & Source of variation & Day 7 & Day 14 & Day 21 & Day 28 & Day 42 \\
\hline \multirow[t]{2}{*}{ Chlorophyll a } & Treatment $(A)$ & $\begin{array}{l}13.08 \\
(0.01)\end{array}$ & $\begin{array}{l}27.97 \\
(0.002)\end{array}$ & $\begin{array}{c}4.16 \\
(0.087)\end{array}$ & $\begin{array}{c}0.49 \\
(0.51)\end{array}$ & $\begin{array}{c}0.54 \\
(0.49)\end{array}$ \\
\hline & Core (Treatment) $\mathrm{B}(\mathrm{A})$ & $\begin{array}{l}5.12 \\
(0.039)\end{array}$ & $\begin{array}{c}8.28 \\
(0.013)\end{array}$ & $\begin{array}{l}11.73 \\
(0.005)\end{array}$ & $\begin{array}{c}2.49 \\
(0.153)\end{array}$ & $\begin{array}{l}5.16 \\
(0.038)\end{array}$ \\
\hline \multirow[t]{2}{*}{ Nematodes } & A & $\begin{array}{c}1.17 \\
(0.30)\end{array}$ & $\begin{array}{c}0.03 \\
(0.88)\end{array}$ & $\begin{array}{c}0.12 \\
(0.73)\end{array}$ & $\begin{array}{c}3.79 \\
(0.08)\end{array}$ & $\begin{array}{c}4.14 \\
(0.06)\end{array}$ \\
\hline & $\mathrm{B}(\mathrm{A})$ & $\begin{array}{c}0.68 \\
(0.62)\end{array}$ & $\begin{array}{l}6.38 \\
(0.005)\end{array}$ & $\begin{array}{c}1.25 \\
(0.34)\end{array}$ & $\begin{array}{l}5.55 \\
(0.009)\end{array}$ & $\begin{array}{c}118.55 \\
(0.000)\end{array}$ \\
\hline \multirow[t]{2}{*}{ Nauplii } & $A$ & $\begin{array}{l}5.22 \\
(0.041)\end{array}$ & $\begin{array}{l}8.51 \\
(0.013)\end{array}$ & $\begin{array}{l}8.78 \\
(0.012)\end{array}$ & $\begin{array}{c}6.32 \\
(0.027)\end{array}$ & $\begin{array}{l}2.29 \\
(0.156)\end{array}$ \\
\hline & $B(A)$ & $\begin{array}{c}0.322 \\
(0.86)\end{array}$ & $\begin{array}{c}4.15 \\
(0.25)\end{array}$ & $\begin{array}{c}1.84 \\
(0.19)\end{array}$ & $\begin{array}{c}2.02 \\
(0.16)\end{array}$ & $\begin{array}{c}1.43 \\
(0.29)\end{array}$ \\
\hline \multirow[t]{2}{*}{ Copepodites } & A & $\begin{array}{l}0.0005 \\
(0.98)\end{array}$ & $\begin{array}{c}2.963 \\
(0.01)\end{array}$ & $\begin{array}{l}16.57 \\
(0.002)\end{array}$ & $\begin{array}{c}0.225 \\
(0.64)\end{array}$ & $\begin{array}{l}18.49 \\
(0.01)\end{array}$ \\
\hline & $\mathrm{B}(\mathrm{A})$ & $\begin{array}{c}3.004 \\
(0.06)\end{array}$ & $\begin{array}{c}0.24 \\
(0.91)\end{array}$ & $\begin{array}{c}2.43 \\
(0.11)\end{array}$ & $\begin{array}{l}2.4 \\
(0.11)\end{array}$ & $\begin{array}{c}5.49 \\
(0.01)\end{array}$ \\
\hline \multirow[t]{2}{*}{ Adult copepods } & A & $\begin{array}{l}10.49 \\
(0.007)\end{array}$ & $\begin{array}{c}0.005 \\
(0.94)\end{array}$ & $\begin{array}{l}3.03 \\
(0.11)\end{array}$ & $\begin{array}{c}0.003 \\
(0.96)\end{array}$ & $\begin{array}{c}0.214 \\
(0.65)\end{array}$ \\
\hline & $\mathrm{B}(\mathrm{A})$ & $\begin{array}{c}0.49 \\
(0.74)\end{array}$ & $\begin{array}{c}1.58 \\
(0.24)\end{array}$ & $\begin{array}{c}1.33 \\
(0.31)\end{array}$ & $\begin{array}{c}1.388 \\
(0.30)\end{array}$ & $\begin{array}{l}1.60 \\
(0.24)\end{array}$ \\
\hline
\end{tabular}

Initially, the mean abundance of harpacticoid copepodites was $10479 \pm 3025$ ind. $\mathrm{m}^{-2}$ (Fig. 5B). On Days 14, 21 and 42, the abundance of harpacticoid copepodites was significantly higher $(47$ to $79 \%$ in the reduced UVB microcosms than in the ambient UVB microcosms (Table 1). Mean abundance of adult stages of harpacticoid copepods was $52400 \pm 13186$ ind $\mathrm{m}^{-2}$ at the beginning of the experiment (Fig. 5C). On Day 7, adult copepods were significantly more abundant in cores exposed to UVB (Table 1). There was no significant difference in abundance between treatments at subsequent sampling dates.

Other components of the meiofauna were present within the cores (i.e. some oligochaetes and turbellarians) but did not seem to be affected by the UVB treatment.

Fig. 4. Temporal variations of (A) chl a areal concentration of intact microbial mats and (B) total abundance of nematodes in sediments exposed to ambient UVB (natural UVB, black bars) or reduced UVB (grey bars) from Day 1 (8 July) to Day 42 (19 August). Bars show mean + $\mathrm{SE}$ of 3 replicate cores. "Significant difference at $p<0.05$
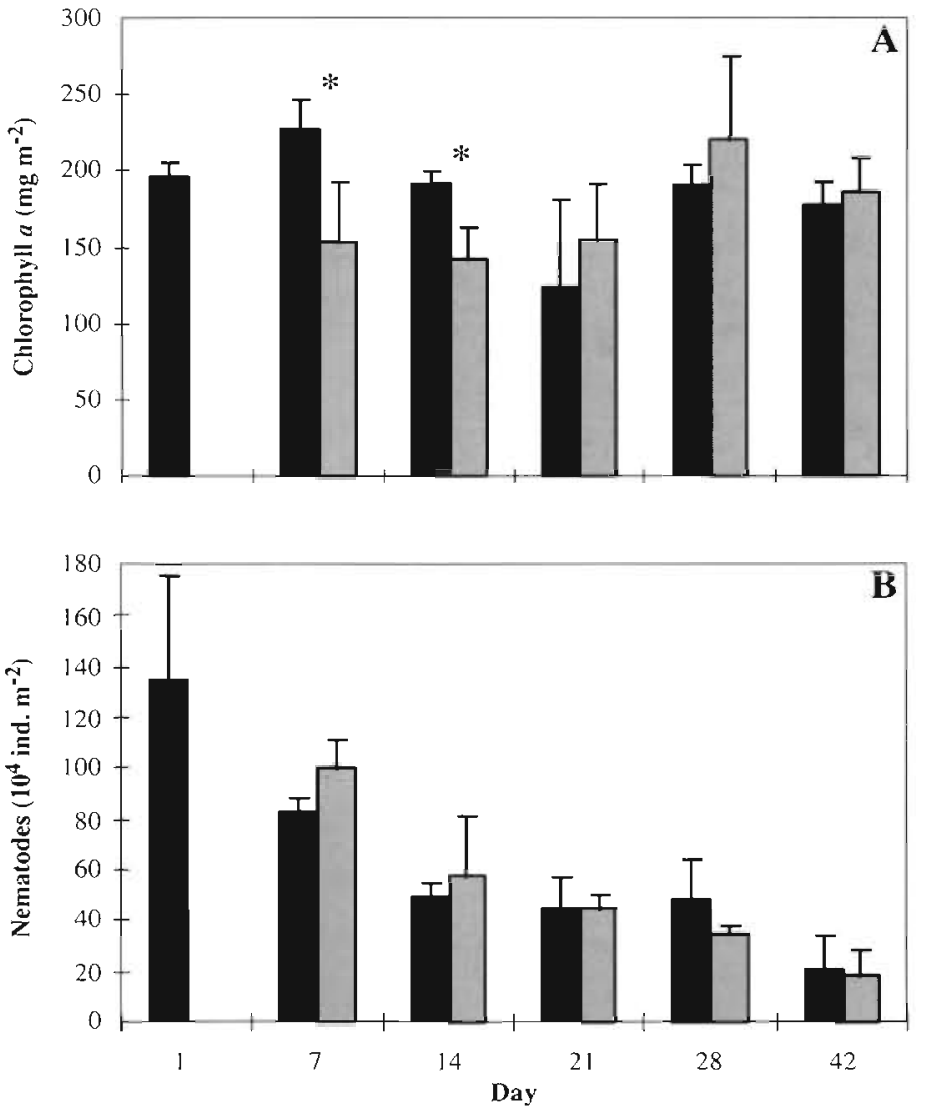

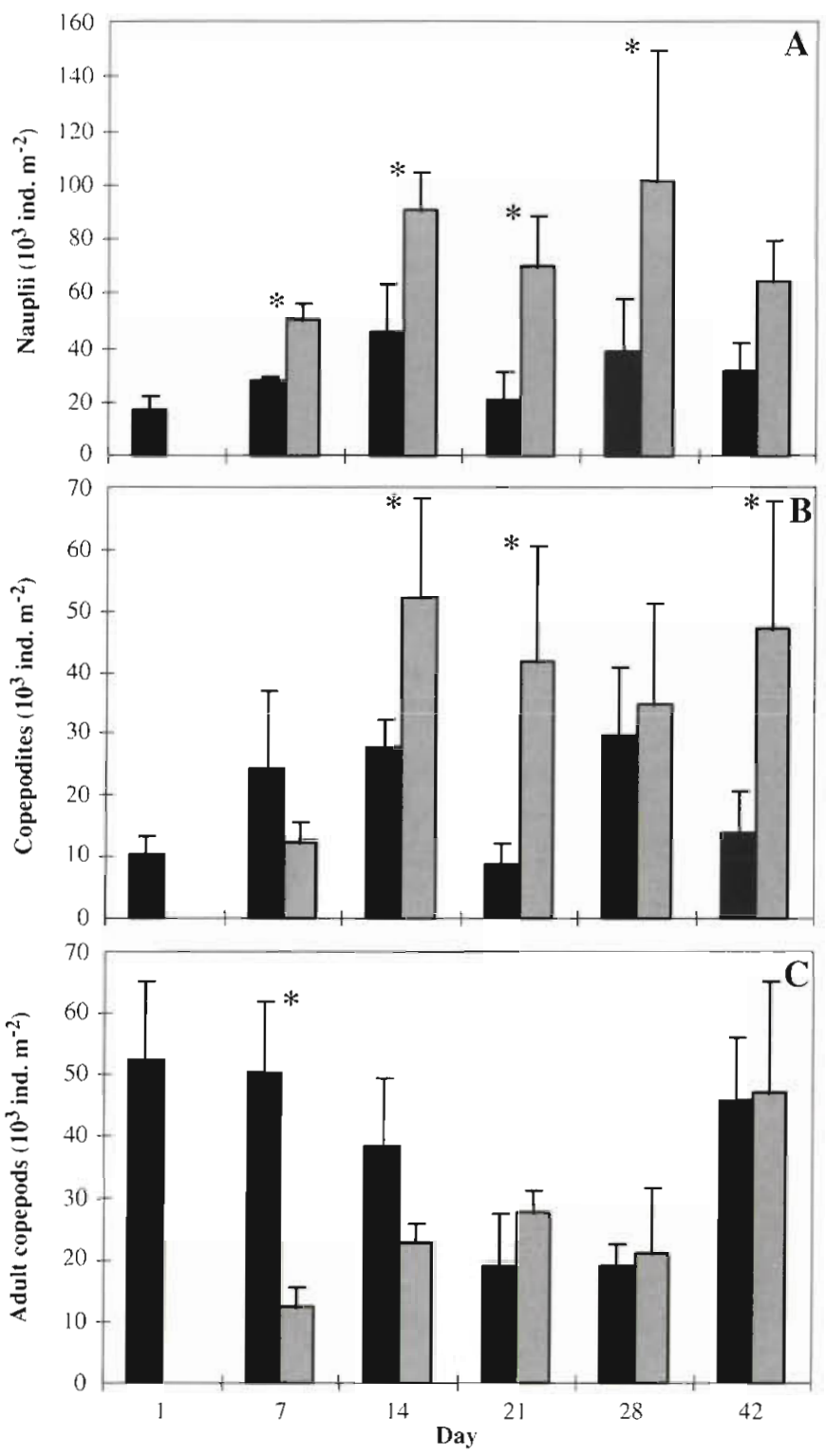

Fig. 5. Temporal variations of total abundance of (A) nauplii, (B) copepodites and (C) adult harpacticoid copepods in sediments exposed to ambient UVB (natural UVB, black bars) or reduced UVB (grey bars) from Day 1 (8 July) to Day 42 (19 August). Bars show mean + SE of 3 replicate cores. "Significant difference at $p<0.05$

\section{DISCUSSION}

Our microcosm experiment assessed the response of a microbenthic community in a tidal mudflat to ambient UVB. This community was exposed to natural light transmitted through cellulose acetate and Mylar D filters. Compared to cellulose acetate filters (control treatment), Mylar D sheets eliminated $75 \%$ of incident UVB, $16 \%$ of incident UVA and $4 \%$ of incident PAR.
Hence, the differences observed between the 2 light regimes are mainly attributed to UVB, with a smaller contribution from lower-wavelength-range UVA.

Several studies have dealt with the effects of UVB on communities inhabiting shallow-water sediments (Sundbäck et al. 1996a, 1997, Odmark et al. 1998). In contrast to these previous studies, tidal changes were considered in the present study. In muds, the meiobenthos is more diverse and abundant in the superficial layers, i.e. in the top few centimeters of the sediment, than deep inside the sediments. It frequently has an epibenthic life style (Giere 1993). At the sampling site, more than $95 \%$ of the nematodes and $75 \%$ of the other taxa are concentrated in the first top $\mathrm{cm}$ of the sediment (Tita pers. comm.). In our experiment, harpacticoid copepods were dominated by Microarthridion littorale, which accounted for $72 \%$ of the total number of copepods. The latter is a common meiobenthic component of estuarine muds worldwide (Morris \& Coull 1992). It is known as epibenthic, typically living at the sediment-water interface in the upper $3 \mathrm{~mm}$ depth zone of the sediment (Fleeger 1979, Warwick \& Gee 1984 ) and feeding on benthic and planktonic diatoms (Decho 1986). The results of this experiment provide, for the first time, evidence of negative impacts of UVB on meiobenthic copepod nauplii and copepodites. Significant effects of UVB on copepod nauplii abundance were observed throughout the present study. It is widely recognized that mortality is generally higher in the naupliar stage than in other developmental stages (Feller 1980). Starvation and predation are typically considered to be the 2 major sources of mortality during the early life stages of copepods (Hicks \& Coull 1983). Since nauplii predators (such as the juveniles of benthic fish or the polychaete Nereis virens; Olivier et al. 1993) were not present, and food (algal biomass) was abundant in the microcosms, nauplii mortality observed in our experiment was essentially related to ambient UVB exposure. As shown in Fig. 5A, the nauplii abundance increased after Day 1 . These new nauplii may come from eggs of ovigerous females already present in the sediment at the time of field sampling, or from eggs laid by reproductive adults during the microcosm experiment. Thus, the higher nauplii abundance observed in the reduced UVB treatment may be related to (1) a higher reproduction rate by adults, (2) higher hatching success, or (3) lower mortality of the nauplii. Significant effects of UVB exposure under laboratory conditions have been reported on nauplii of planktonic copepods (Karanas et al. 1979, Keller et al. 1997). Karanas et al. (1979) reported that the most susceptible life stages of Acartia clausii to UVB exposure was the $N_{5} / N_{6}$ nauplii group. Chalker-Scott (1995) found that the different life stages of the suprabenthic free-swimming harpacticoid copepod Tigriopus cali- 
fornicus were highly tolerant to enhanced UVB. Yet, the latter reported a negative survival rate for the irradiated $N_{5} / N_{6}$ stages (Chalker-Scott 1995). The occurrence of lower copepodite abundances on 3 sampling dates in the natural UVB treatment (Fig. 5B) may be attributed to a lower nauplii survival rate, or to a direct negative effect of UVB on the copepodites. The reasons driving the sudden increase in copepod abundance observed on Day 7 in the ambient UVB treatment are not known. A possible explanation could be patchiness resulting from the spatial variation of food resources (Pinckney \& Sandulli 1990). We did not find any significant UVB effects on the abundance of adult copepods on subsequent sampling dates. The duration of our experiment ( $6 \mathrm{wk})$ may not have been long enough to detect any measurable impacts of UVB on adult copepods. Karanas et al. (1981) showed that sublethal effects can result in physiological or behavioral changes that may, over time, have a significant impact on the population of $A$. clausii. It has been demonstrated that sex changes in harpacticoids may be influenced by a great range of environmental and biotic variables (Hicks \& Coull 1983). Chalker-Scott (1995) reported a sex ratio shift in adults that developed from the youngest naupliar stages $\left(\mathrm{N}_{1} / \mathrm{N}_{2}\right)$ of $T$. californicus that were exposed to increased UVB. Whether solar UVB affects harpacticoid copepods of mud sediments in terms of sex ratio has not been determined in our study, but needs to be addressed in future experiments. The latter should be developed under time periods long enough to detect possible changes in population structure of harpacticoid copepods. The difficulty in measuring turnover rates of the different copepod life stages in the field (Morris \& Coull 1992) prevented a detailed analysis of cohorts succession in the present experiment. Development rates in harpacticoids are known to be highly temperature-dependent (Hicks \& Coull 1983). For instance, Palmer \& Coull (1980) reported from a laboratory study that embryonic rates ranged from a mean of $8.7 \mathrm{~d}$ at $10^{\circ} \mathrm{C}$ to $1.6 \mathrm{~d}$ at $36^{\circ} \mathrm{C}$, while nauplii and copepodite development rates at 15 to $33^{\circ} \mathrm{C}$ ranged from 30.4 to $7.9 \mathrm{~d}$ and 27 to $10.1 \mathrm{~d}$, respectively. Nevertheless, our results suggest that benthic nauplii represent the life-stage more sensitive to UVB. We did not find any significant UVB effects on nematode abundance. This result may be related to the fact that these organisms are preferentially located deeper in the sediment and are never found active in the surface layer (Giere 1993). Some argue that the drastic decrease of nematodes may be the result of a high temperature effect (Giere 1993). However, the temperature measured in our microcosm was comparable to those recorded in the field at the same location. Therefore, this result could be attributed to a confinement effect.
A significant decrease in chl a concentrations was observed in the reduced UVB microcosms on Days 7 and 14, and no significant difference was observed thereafter. In a microtidal area on the west coast of Sweden, Sundbäck et al. (1996a) did not find any significant differences in algal biomass, but reported a tendency for higher chl a concentrations in reduced UVB microcosms. The fact that chl a concentration reflects the balance between algal growth and grazing makes it difficult to predict the response of microphytobenthos to UVB. It seems likely that oxygen production or carbon assimilation rates would be more appropriate tools to assess the direct UVB impact on microphytobenthos (Sundbäck et al. 1997, Odmark et al. 1998). Along the same line, Karentz \& Spero (1995) suggested that the overall physiological effect of UVB on algal communities is probably a shift in the balance between photosynthesis and respiration. Nevertheless, the higher abundance of copepod nauplii and copepodites generally observed in microcosms shielded from UVB may lead to increased grazing pressure on the microphytobenthos. In intertidal habitats, microphytobenthos is recognized as an important food source for meiofauna (Montagna 1984). In sandy sediments, these organisms may even significantly affect microalgal biomass (Sundbäck et al. 1996b). Harpacticoids, in particular, have a dependent relationship with their autotrophic food resources and are known to regulate their behavior to maximize food intake (Montagna et al. 1995). This can explain the lower chl a concentration observed on Days 7 and 14. Bothwell et al. (1994) demonstrated that an increase of algal biomass in treatments exposed to UVR+PAR resulted in part from the disappearance of grazing invertebrates. In the present study, no change in algal biomass was detected during the last $3 \mathrm{wk}$ of the experiment. Since the meiofauna presumably still exerted a higher grazing pressure in the reduced UVB treatment, the similar chl a concentration measured in the 2 treatments would suggest that algal growth was lower under natural UVB conditions. Even if daily UVB doses had begun to decrease at the end of the experiment, the algal community still would have had insufficient time to become acclimated to the prevailing conditions (either through species replacement, or via induction of defense mechanisms).

Laboratory and microcosm studies with meiofauna are usually criticized for being 'unnatural' and conducted under different conditions to those in the field (Coull \& Chandler 1992). However, with respect to UV effects on microbenthic communities, microcosm experiments present several advantages over other approaches. They enable (1) a controlled alteration of the ambient irradiance, (2) a realistic reproduction of natural irradiance, (3) long-term observations, and 
(4) the possible assessment of community-level effects (Belzile et al. 1998). Although field studies can also meet some of these requirements, the large spatiotemporal variability of environmental factors encountered in the intertidal zone may complicate the detection of UVB-specific effects. During the present experiment, the abundance of benthic nauplii and copepodites increased relative to Day 1 and may have resulted in the appearance of a new cohort of adults on Day 42 (Fig. 5C). Together with maintained chl a concentrations, these results reveal that the conditions prevailing in the microcosms mimicked the natural conditions which would occur in the absence of higherlevel predators. The presence of semidiurnal tides in the microcosms provided some protection for the organisms, due to the attenuation of UV irradiance by the water. However, since the water was filtered on $1 \mu \mathrm{m}$ cartridge filters, that effect was probably very small. It should be noted that the absorption of UVB by chromophoric dissolved organic matter (CDOM) could be relatively high in the Lower St. Lawrence Estuary (Nieke et al. 1997). That protective effect of the water column might be more important in the intertidal zone, owing to a greater tidal amplitude (the maximum tidal amplitude is about $2 \mathrm{~m}$ ), and higher attenuation by particulate and dissolved matter. Whether in microcosms or in the field, future studies on the effects of UV radiation on intertidal meiobenthic communities should include assessments of the water UVB-absorbing properties. This will enable us to interpret results in ecological terms.

In terms of abundance and diversity, meiofauna is one of the main constituents of the benthic ecosystem. It plays a key role in the energy fluxes through the entire benthic food web (Bell \& Coull 1980, Tenore \& Rice 1980, Platt 1981, Rudnick 1989, Blanchard 1991, Nilsson et al. 1991, Aller \& Aller 1992). For example, meiobenthic individuals which colonize the surface of the sediments are a source of food for larger metazoans (Reise 1985) and influence the solute exchange at the water-sediment interface by bioturbation (Aller \& Aller 1992). In this study, natural UVB had a deleterious effect on the naupliar stages of harpacticoid copepods, a key group of the meiobenthic compartment. The meiobenthic populations have a rapid turnover rate, and a change in UVB may greatly influence the dynamics of intertidal populations of copepods by affecting their recruitment. The structural changes in these populations induced by UVB may significantly reduce nutrient transport at the water-sediment interface and the availability of food in the upper trophic levels.

Acknowledgements. This work was supported by grants from NSERC (Natural Sciences and Engineering Research Council of Canada), Fonds FCAR (Fonds pour la formation des chercheurs et l'aide à la recherche) of Québec and FODAR (Fonds pour le développement et l'avancement de la recherche, Université du Québec). C.N. received a postdoctoral fellowship from MEQ (Ministère de l'Education du Québec), FUQAR (Fondation de l'Université du Québec à Rimouski) and GREC (Groupe de recherche en environnement côtier). We thank C. A. Darveau, D. Bourget and A. Weise for technical assistance; $B$. Mostajir for constructive discussion; F. Charles and 4 anonymous referees for insightful comments on the manuscript ${ }_{i}$ and $M$. Joanette, director of the Parc national du $\mathrm{Bic}_{1}$ and the Department of Fisheries and Oceans Canada for allowing us to collect sediment samples in the Parc national du Bic. This is a contribution to the research programs of GREC.

\section{LITERATURE CITED}

Adams NL, Shick JM (1996) Mycosporine-like amino acids provide protection against ultraviolet radiation in eggs of the green sea urchin Strongylocentrotus droebachiensis. Photochem Photobiol 64:149-158

Aller RC, Aller JY (1992) Meiofauna and solute transport in marine muds. Limnol Oceanogr 37:1018-1033

Bell SS, Coull BC (1980) Experimental evidence for a model of juvenile macrofauna-meiofauna interactions. In: Tenore KR, Coull BC (eds) Marine benthic dynamics. University of South Carolina Press, Columbia, p 179-192

Belzile C, Demers S, Lean DRS, Mostajir B, Roy S, de Mora S, Gosselin M, Bird D, Chanut JP, Levasseur M (1998) An experimental tool for the study of the effects of ultraviolet radiation on planktonic communities: a mesocosm approach. Environ Technol 19:667-682

Biermann CH, Schinner GO, Strathmann RR (1992) Influence of solar radiation, microalgal fouling, and current on deposition site and survival of embryos of a dorid nudibranch gastropod. Mar Ecol Prog Ser 86:205-215

Blanchard GF (1991) Measurement of meiofauna grazing rates on microphytobenthos: is primary production a limiting factor? J Exp Mar Biol Ecol 147:37-46

Bothwell ML, Sherbot DMJ, Roberge AC, Daley RJ (1993) Influence of natural ultraviolet radiation on lotic periphytic diatom community growth, biomass accrual, and species composition: short-term versus long-term effects. J Phycol 29:24-35

Bothwell ML, Sherbot DMJ, Pollock CM (1994) Ecosystem response to solar ultraviolet- $B$ radiation: influence of trophic-Ievel interactions. Science 265:97-100

Buma AGJ, Zemmelink HJ, Sjollema K, Gieskes WWC (1996) UVB radiation modifies protein and photosynthetic pigment content, volume and ultrastructure of marine diatoms. Mar Ecol Prog Ser 142:47-54

Chalker-Scott L. (1995) Survival and sex ratios of the intertidal copepod, Tigriopus californicus, following ultraviolet-B (290-320 nm) radiation exposure. Mar Biol 123:799-804

Coull BC, Bell SS (1979) Perspective in marine meiofaunal ecology. In: Livingston RJ (ed) Ecological processes in coastal and marine systems. Plenum Press, New York, p $189-216$

Coull BC, Chandler GT (1992) Pollution and meiofauna: field, laboratory, and mesocosm studies. Oceanogr Mar Biol Annu Rev 30:191-271

Cullen JJ, Lesser M (1991.) Inhibition of photosynthesis by ultraviolet radiation as a function of dose and dosage rate: results for a marine diatom. Mar Biol 111:183-190

Decho AW (1986) Water-cover influences on diatom ingestion 
rates by meiobenthic copepods. Mar Ecol Prog Ser 33 $139-146$

Desrosiers G, Olivier M, Vincent B (1991) Variations de la densité et de la croissance des recrues de l'annélide polychète Nereis virens (Sars) en zone intertidale. Can J Zool 69:560-566

Dionne JC (1977) La mer de Goldthwait au Québec. Geogr Phys Quat 31:61-80

Farman JC, Gardiner BG, Shanklin JD (1985) Large losses of total ozone in Antarctica reveal seasonal $\mathrm{CO}_{x} / \mathrm{NO}_{x}$ interaction. Nature 315:207-210

Feller RJ (1980) Development of the sand-dwelling meiobenthic harpacticoid copepod Huntemannia jadensis Poppe in the laboratory. J Exp Mar Biol Ecol 46:1-15

Fleeger JW (1979) Population dynamics of three estuarine meiobenthic harpacticoids (Copepoda) in South Carolina Mar Biol 52:147-156

Garcia-Pichel F (1995) A scalar irradiance fiber-optic microprobe for the measurement of ultraviolet radiation at high spatial resolution. Photochem Photobiol 61:248-254

Garcia-Pichel F, Bebout BM (1996) Penetration of ultraviolet radiation into shallow water sediments: high exposure for photosynthetic communities. Mar Ecol Prog Ser 131 $257-262$

Garcia-Pichel F, Castenholz RW (1994) On the significance of solar ultraviolet radiation for the ecology of microbial mats. In: Stal LJ, Caumette P (eds) Microbial mats. NATO A.SI Series G: Ecological sciences, Vol 35. Springer Verlag, Berlin, p 77-84

Giere O (1993) Meiobenthology - the microscopic fauna in aquatic sediments. Springer-Verlag, Berlin

Gleason DF, Wellington GM (1993) Ultraviolet radiation and coral bleaching. Nature 365:836-838

Gleason DF, Wellington GM (1995) Variation in UVB sensitivity of planula larvae of the coral Agaricia agaricites along a depth gradient. Mar Biol 123:693-703

Häder DP (1993) Risks of enhanced solar ultraviolet radiation for aquatic ecosystems. In: Round FE, Chapman DJ (eds) Progress in phycological research, Vol 9. Biopress Ltd, Bristol, p 1-45

Herndl GJ, Müller-Nicklas G, Frick J (1993) Major role of ultraviolet-B in controlling bacterioplankton growth in the surface layer of the ocean. Nature 361:717-719

Hicks GRG, Coull BC (1983) The ecology of marine meiobenthic harpacticoid copepods. Oceanogr Mar Biol Annu Rev $21: 67-175$

Hill WR, Dimick SM, McNamara AE, Branson CA (1997) No effects of ambient UV radiation detected in periphyton and grazers. Limnol Oceanogr 42:769-774

Karanas JJ, Van Dyke H, Worrest RC (1979) Mid-ultraviolet (UV-B) sensitivity of Acartia clausii Giesbrecht (Copepoda). Limnol Oceanogr 24:1104-1116

Karanas JJ, Worrest RC, Van Dyke H (1981) Impact of UV-B radiation on the fecundity of the copepod Acartia clausii. Mar Biol 65:125-134

Karentz D (1994) Ultraviolet tolerance mechanisms in Antarctic marine organisms. In: Weiler CS, Penhale PA (eds) Ultraviolet radiation in Antarctica: measurements and biological effects. Antarctic Res Ser 62. American Geophysical Union, Washington, DC, p 93-110

Karentz D, Spero HJ (1995) Response of a natural Phaeocystis population to ambient fluctuations of UV-B radiation caused by Antarctic ozone depletion. J Plankton Res 17:1771-1789

Karentz D, McEuen FS, Land MC, Dunlap WC (1991) Survey of mycosporine-like amino acid compounds in Antarctic marine organisms: potential protection from ultraviolet exposure. Mar Biol 108:157-166
Keller A.A, Hargraves P, Jeon H, Klein-MacPhee G, Klos E, Oviatt C, Zhang J (1997) Effects of ultraviolet-B enhancement on marine trophic levels in a stratified coastal system. Mar Biol 130:277-287

Kerr JB, McElroy CT (1993) Evidence for large upward trends of ultraviolet- $B$ radiation linked to ozone depletion. Science 262:1032-1034

Kiffney PM, Clements WH, Cady. TA (1997) Influence of ultraviolet radiation on the colonization dynamics of a Rocky Mountain Stream benthic community. J Nat Am Benthol Soc 16:520-530

Lesser MP, Lewis S (1996) Action spectrum for the effects of UV radiation on photosynthesis in the hermatypic coral Pocillopora damicornis. Mar Ecol Prog Ser 134:171-177

Lubin D, Jensen EH (1995) Effects of clouds and stratospheric ozone depletion on ultraviolet radiation trends. Nature 377:710-713

McClintock JB, Karentz D (1997) Mycosporine-like amino acids in 38 species of subtidal marine organisms from McMurdo Sound Antarctica. Antarct Sci 9:392-398

Miron G (1988) Distributions et variations intra-populations de trois espèces de polychètes de la baie de l'Anse-àl'Orignal, Parc du Bic, Rimouski. Masters thesis, Université du Québec à Rimouski

Miron G, Desrosiers G (1990) Distributions and population structures of two intertidal estuarine polychaetes in the Lower St. Lawrence Estuary, with special reference to environmental factors. Mar Biol 105:297-306

Montagna PA (1984) In situ measurement of meiobenthic grazing rates on sediment bacteria and edaphic diatoms. Mar Ecol Prog Ser 18:119-130

Montagna PA, Blanchard GF, Dinet A (1995) Effect of production and biomass of intertidal microphytobenthos on meiofaunal grazing rates. J Exp Mar Biol Ecol 185:149-165

Morgan SG, Christy JH (1996) Survival of marine larvae under the countervailing selective pressures of photodamage and predation. Limnol Oceanogr 41:498-504

Morris JT, Coull BC (1992) Population dynamics, numerical production, and potential predation impact on meiobenthic copepod. Can J Fish Aquat Sci 49:609-616

Mostajir B, Demers S, de Mora S, Belzile C, Chanut JP, Gosselin M, Roy S, Zulema Villegas P, Fauchot J, Bouchard J, Bird D, Monfort P, Levasseur M (1999) Experimental test of the effect of ultraviolet-B radiation in a planktonic community. Limnol Oceanogr 44: 586-596

Müller R, Crutzen PJ, Grooß JU, Brühl C, Russel JM III, Gernandt $H$, McKenna DS, Tuck AF (1997) Severe chemical ozone loss in the Arctic during the winter of 1995-96. Nature 389:709-712

Nieke B, Reuter R, Heuermann $H$, Wang $H$, Babin $M$, Therriault JC (1997) Light absorption and fluorescence properties of chromophoric dissolved organic matter (CDOM), in the St. Lawrence Estuary (Case 2 waters). Cont Shelf Res 17:235-252

Nilsson P, Jönsson B, Lindström Swanberg I, Sundbäck K (1991) Response of a marine shallow-water sediment system to an increased load of inorganic nutrients. Mar Ecol Prog Ser 71:275-290

Odmark S, Wulff A, Wängberg SA, Nilsson C, Sundbäck K (1998) Effects of UVB radiation in a microbenthic community of a marine shallow-water sandy sediment. Mar Biol 132:335-345

Olivier M, Desrosiers G, Retière C, Brêthes JCF (1993) Variations spatio-temporelles de l'alimentation chez le polychète Nereis virens (Sars) en zone intertidale (Estuaire maritime du Saint-Laurent, Québec). Vie Milieu 43:1-12 Palmer MA, Coull BC (1980) The prediction of development 
rate and the effect of temperature for the meiobenthic copepod, Microarthridion littorale (Poppe). J Exp Mar Biol Ecol 48:73-83

Peletier H, Gieskes WWC, Buma AGJ (1996) Ultraviolet-B radiation resistance of benthic diatoms isolated from tidal flats in the Dutch Wadden Sea. Mar Ecol Prog Ser 135: $163-168$

Pennington JT, Emlet RB (1986) Ontogenetic and diel vertical migration of a planktonic echinoid larva, Dendraster excentricus (Eschscholtz): occurrence, causes, and probable consequences. J Exp Mar Biol Ecol 104:69-95

Pinckney J, Sandulli R (1990) Spatial autocorrelation analysis of meiofaunal and microalgal populations on an intertidal sandflat: scale linkage between consumers and resources. Estuar Coast Shelf Sci 30:341-353

Pinckney J, Zingmark RG (1993) Biomass and production of benthic microalgal communities in estuarine habitats. Estuaries 16:887-897

Platt HM (1981) Meiofaunal dynamics and the origin of the metazoa. In: Greenwood PH (ed) The evolving biosphere. Cambridge University Press, Cambridge, p 207-216

Rawlings TA (1996) Shields against ultraviolet radiation: an additional protective role for the egg capsules of benthic marine gastropods. Mar Ecol Prog Ser 136:81-95

Reise K (1985) Tidal flat ecology. An experimental approach to species interactions. Springer-Verlag, Berlin

Rex M, Harris NRP, von der Gathen P, Lehmann $R$, Braathen GO, Reimer E, Beck A, Chipperfield MP, Alfier R, Allaart M, O'Connor F, Dier H, Dorokhov V, Fast H, Gil M, Kyrö E, Litynska Z, Mikkelsen IS, Molyneux MG, Nakane $H$, Notholt J, Rummukainen M, Viatte P, Wenger J (1997) Prolonged stratospheric ozone loss in the 1995-96 Arctic winter. Nature 389:835-838

Riaux-Gobin C, Klein B (1993) Microphytobenthic biomass measurement using HPLC and conventional pigment analysis. In: Kemp P, Sherr B, Sherr E, Cole J (eds) Handbook of methods in aquatic microbial ecology. Lewis Publishers, Boca Raton, p 369-376

Rudnick DT (1989) Time lags between the deposition and meiobenthic assimilation of phytodetritus. Mar Ecol Prog Ser 50:231-240

Editorial responsibility: Otto Kinne (Editor), Oldendorf/Luhe, Germany
Shick JM, Dunlap WC, Chalker BE, Banaszak AT, Rosenzweig TK (1992) Survey of ultraviolet radiation absorbing mycosporine-like amino acids in organs of coral reef holothurids. Mar Ecol Prog Ser 90:139-148

Smith RC, Baker KS, Holm-Hansen O, Olson R (1980) Photoinhibition of photosynthesis in natural waters. Photochem Photobiol 31:585-592

Strickland JDH, Parsons TR (1972) A practical handbook of seawater analysis. Bull Fish Res Board Can 167:1-310

Sundbäck K, Nilsson C, Odmark S, Wulff A (1996a) Does ambient UV-B radiation influence marine diatom-dominated microbial mats? A case study. Aquat Microb Ecol 11:151-159

Sundbäck K, Nilsson P, Nilsson C, Jönsson B (1996b) Balance between autotrophic and heterotrophic components and processes in microbenthic communities of sandy sediments: a field study. Estuar Coast Shelf Sci 43:689-706

Sundbäck $K$, Odmark $S$, Wulff $A$, Nilsson $C$, Wänberg SA (1997) Effects of enhanced UVB radiation on a marine benthic diatom mat. Mar Biol 128:171-179

Tenore KR, Rice DL (1980) A review of trophic factors affecting secondary production of deposit-feeders. In: Tenore $\mathrm{KR}$, Coull BC (eds) Marine benthic dynamics. University of South Carolina Press, Columbia, p 325-340

Thorson G (1964) Light as an ecological factor in the dispersal and settlement of marine bottom invertebrates. Ophelia 1: $167-208$

Underwood AJ (1981) Techniques of analysis of variance in experimental marine biology and ecology. Oceanogr Mar Biol Annu Rev 19:513-605

Vincent WF, Quesada A (1994) Ultraviolet radiation effects on cyanobacteria: implications for Antarctic microbial ecosystems. In: Weiler CS, Penhale PA (eds) Ultraviolet radiation in Antarctica: measurements and biological effects. Antarct Res Ser 62. American Geophysical Union, Washington, $D C, p$ 111-124

Warwick RM, Gee JM (1984) Community structure of estuarine meiobenthos. Mar Ecol Prog Ser 18:97-111

Williamson CE (1995) What role does UV-B radiation play in freshwater ecosystems? Limnol Oceanogr 40 : $386-392$

Submitted: December 1, 1998; Accepted: June 10, 1999 Proofs received from author(s): November 1, 1999 